\title{
George Philip
}

\section{The New Populism, Presidentialism and Market-Orientated Reform in Spanish South America}

A SIGNIFICANT DEVELOPMENT IN RECENT SOUTH AMERICAN POLITICS has been the re-emergence of populism. More interesting still has been the unexpected combination - in some countries - of traditional populist appeals (successfully made), the determined application of free market policies, and the successful re-election of the market-reforming populists. This does not mean that populist politicians can succeed to order. Many populist candidates have sought election and only a few have secured it. Of those elected as (essentially) independent candidates, only some have succeeded. Presidents Bucaram in Ecuador and Collor in Brazil were removed from office by Congress and subjected to legal proceedings for corruption. However, where populists have succeeded, they have done so on a far more impressive scale than most people originally predicted. Peru's Fujimori has been more ambitious as a reformer than any Peruvian president this century, while Argentina's Menem can claim to have presided over the reversal of that country's post1930 economic decline. Both Peru and Argentina have already started to enjoy significant medium-term improvements in economic performance as a result of structural reforms undertaken since $1990 .^{1}$ Both Fujimori and Menem were also able to secure re-election. Caldera in Venezuela belongs to the category of success stories as well, although his policy style is more gradualist than those of Menem or Fujimori. Here, too, there are signs that a long cycle of economic decline and political frustration is at last being reversed.

This article is not so much an attempt to characterize the new populism as to assess its significance. The argument can be stated quite briefly. The new populism (like the old) has a symbiotic

\footnotetext{
1 Inter-A merican Development Bank, Economic and Social Progress in Latin America: 1996 Report, Washington, IDB, 1996, p. 33.
} 
relationship with presidentialism. The combination is capable of generating increasing returns to power, at any rate for a period. These increasing returns allowed a period of presidential ascendancy and the temporary weakening of both non-presidential institutions and veto groups attached to them. This, in turn, allowed the populists to push through radical market-orientated reforms in a democratic context. These reforms have had a considerable impact on the medium-term economic performance of Peru, Argentina and Venezuela. A temporary period of hyper-presidentialism was much less damaging to democracy than would have been the likely alternative - namely prolonged institutional crisis of a kind threatening to democratic stability.

While this outcome has been rather benign, it has also been unexpected. Awareness that increasing returns to power (and therefore radical change from above) are sometimes compatible with democracy is largely lacking in the 'politics of development' literature. This observation will be substantiated in more detail below. Furthermore this literature is often sceptical (normatively as well as empirically) of the virtues of strong central government. This scepticism is sometimes justified but not invariably so. The final section of this discussion seeks to draw some more nuanced conclusions from the emergence of the new populism.

We start, though, with a brief description of the events themselves. Menem, Fujimori and Caldera were elected president despite running as outsiders. Fujimori emerged from almost total obscurity to win the Peruvian presidency in 1990 . Menem, while always a Peronist, defeated the official party machinery to win the nomination of that party and thereafter the presidency. Caldera, while associated for many years with the Christian Democrat Party (COPEI) in Venezuela, left that party and won the presidency in 1993 as a personalist figure at the head of a loose coalition of minority parties.

All of them won election at a time of severe crisis. There was almost constant military unrest in Argentina between 1988 and 1990. Peru in 1990 faced two major civil insurgencies (from Sendero Luminoso and the MRTA), and it was common knowledge that military intervention was a serious possibility. There were two coup attempts in Venezuela in 1992 and the impeachment for corruption of President Carlos Andres Perez took place in 1993. While 
democracy may not be completely re-secured in all of these countries today, the prospects for democracy are surely better in all three cases than in 1990.

All three presidents have also been associated with radical policies of economic reform which include but extend far beyond the fiscal discipline sought by the IMF and other international financial institutions. They all won election on broadly anti-stabilization platforms but found it necessary to resort to orthodox policies when in government. This fact on its own need not cause surprise. What is noteworthy is that the reforms have been extremely extensive in all cases. There has been radical privatization in Argentina and Peru and a continuing programme of privatization in Venezuela. ${ }^{2}$ Privatization apart, there has been a wholesale slaughter of sacred cows in all three countries. Venezuela has distanced itself from OPEC and partly reversed the oil nationalization of 1976. Argentina abandoned its 'non-aligned' foreign policy, tying its currency to the dollar and its international outlook to Nato. British and Argentinian forces fought on the same side in the Gulf War in 1991. Peru has radically reformed its education system (particularly in higher education), while Fujimori has ignored strong criticism from the Church and pushed on with a strong birth control programme. All three countries have adopted labour reforms and pension reforms. Both Venezuela and Argentina now have a high degree of foreign ownership of their banking systems (once considered the stronghold of dominant local capitalists) while the newly-adopted Peruvian constitution explicitly states that foreigners have property rights equal to those of Peruvian citizens.

If we turn our attention to political style, we see that there is a strong centralizing streak in all three cases. All at times used decree powers in order to bypass Congress, though in the cases of Menem and Caldera only to the extent constitutionally permitted. However, all three presidents have issued sweeping legislation in order to bring about economic reform. Caldera in June 1994 declared a state of economic emergency (which a Venezuelan president is constitutionally empowered to do). This was followed by a number of police raids and some, mostly temporary, arrests of Venezuelans on

\footnotetext{
2 On Argentinian privatization, see P. Calvert, 'Privatisation in Argentina', Bulletin of Latin American Research, 15: 2. On Peru, see B. Kay, " "Fujipopulism" and the Liberal State in Peru', Journal of Inter-A merican Studies, 38: 4 (Winter 1996-97).
} 
suspicion of corruption. In July Congress voted to restore constitutional guarantees and several congressmen denounced heavyhanded government policing. One day later, Caldera reimposed the state of emergency. Caldera then made it clear that any further conf lict on this issue would be resolved by referendum, with Caldera agreeing to resign if he lost. Opinion polls suggested that Caldera would win a referendum held on this issue and the opposition parties, realizing that they were unlikely to win, quietly backed down. Having achieved a position of strength, Caldera then quietly negotiated with the opposition and subsequently faced many fewer problems with Congress than had earlier seemed likely.

Menem, like Caldera, has used the powers of the presidency to the full. To take an example, Argentina's Public Sector Reform Law gave Menem the right to privatize state assets without the further approval of Congress. Menem also accepted political support from, and later negotiated directly with military officers associated in the past with extreme nationalist positions and unconstitutional behaviour. ${ }^{3}$ It is clear that he did so only in order to defuse the threat of further military rebellion, and not to militarize his own administration.

Fujimori went further still. He began by using the decree powers which, according to his own lawyers, were vested in the 1979 Constitution. By the end of 1991 he had enacted - without the support of Congress - around 120 laws which introduced a range of neo-liberal measures including the ending of restrictions on the sale of land, and significant de-regulation of the labour market. ${ }^{4}$ He also significantly increased the autonomy and powers of the military. However, early in 1992 Congress fought back and approved a law which would have restricted the powers of the presidency. Fujimori then, in April 1992, called in the security forces to close Congress and purge the judiciary. This step was obviously unconstitutional. Nevertheless, according to a public opinion survey taken at the time, 88 per cent of respondents approved the President's decision to close the legislature and 94 per cent approved his plan to reform the judiciary. ${ }^{5}$

'D. Norden, Military Rebellion in Argentina: Between Coups and Consolidation, Lincoln, Nebr., University of Nebraska Press, 1996.

'P. Mauceri, 'State Reform Coalitions and the Neoliberal Autogolpe in Peru', Latin American Research Review 30: 1 (Winter 1995).

${ }^{3}$ E. Ferrero Costa, 'Peru's Presidential Coup', Journal of Democracy, 4 (January 1993). 
Fujimori was subsequently able to engineer a re-entry into constitutional politics by organizing elections for a new constituent assembly later in 1992. A revised constitution was approved by Peruvian voters in a referendum in October 1993. Fujimori's reelection in 1995 was reinforced by the victory of his supporters in congressional elections held at the same time. Between 1993 and 1996, Fujimori's popularity was unprecedented in twentieth-century Peru, where it has been normal for presidential popularity to decline sharply during incumbency. Some decline in popularity did, however, take place in 1997.

The association of populism with free-market economics is significant. In the past, some writers have tended to define populism primarily in economic terms ${ }^{6}-$ a definition which now seems beside the point. However, much current commentary on politics in South America tends to overlook the significance of this new pattern of politics. A possible reason is that the paradigms elaborated in the 'politics of development' literature earlier in this decade still have resonance despite the subsequent falsification of some of their core hypotheses. The next section of this article looks critically at three kinds of literature - public choice theory, Northian institutionalism and a comparative study of the politics of adjustment - and shows how some of their key assumptions have been undermined by the new populism. The main shortcoming of all three approaches is an inadequate understanding of the uses to which political power can be put.

\section{PUBLIC CHOICE AND ECONOMIC REFORM}

Przeworski is a leading student of market-orientated reform in Latin America from a public choice perspective. ${ }^{7}$ In policy terms, his preferences are almost identical with those of the new populists. All three would surely have agreed with Przeworski that 'profound economic reforms must be undertaken if there is to be any hope that the deterioration in living conditions experienced by many

\footnotetext{
${ }^{6} \mathrm{R}$. Dornbusch and S. Edwards (eds), The Macroeconomics of Populism in Latin America, Chicago, University of Chicago Press, 1991.

${ }^{7}$ A. Przeworski, Democracy and the Market: Political and Economic Reforms in Eastern Europe and Latin America, Cambridge, Cambridge University Press, 1991.
} 
nascent democratic countries will ever cease'. ${ }^{8}$ Przeworski also favours what he calls the 'bitter pill' strategy - in other words a shock-strategy reform rather than slow progressive change. This is very much what happened in Peru and Argentina - although Venezuela has adopted a more gradual pattern.

However, a reading of Przeworski leads one to suppose that no strategy holds out much hope of success in a democratic Latin American context. His main concern was that reform efforts in Eastern Europe would fail and that this region would become more like Latin America. The problem was that governments attempting radical market-orientated reforms would, in Przeworski's view, eventually lose popular support and abandon their policies. This prediction was essentially falsified by Menem and Fujimori (and to some extent Caldera also) and it is instructive to consider why.

There seem to be two kinds of problem with Przeworski's analysis, one specific to his own work and the other inherent in almost any public-choice approach. The specific problem is that Przeworski seems to have underestimated the advantages accruing to 'bitter pill' strategies through bringing down the rate of inflation (particularly hyperinflation) and through successfully privatizing state assets. Taken together, these two factors may well have made the difference between success and failure in both the Peruvian and Argentinian cases. (Venezuela, being a major oil exporter, faces a different set of policy choices.) Przeworski does discuss inflation in his work, though rather briefly. He sees it principally as a problem associated with economic adjustment measures. ${ }^{9}$ However, he does not develop the perception that falling inflation may strengthen the forces pushing for reform. In fact, however, inflation is a key political variable - in South America as elsewhere. Where hyperinflation has existed (as in Peru and Argentina - and also Bolivia), it may be that voter preferences will be altered for years to come.

It is generally the case that market-orientated reforms will tend to reduce inflation before promoting growth, so any reforming government will benefit from the former before the latter. Empirically we know that Fujimori's popularity had already begun to recover strongly during the second part of 1991, when inflation

8 Ibid., p. 189.

9 Ibid., pp. 147-51. 
was clearly falling even though the economy was still stagnant. This enabled him to win his confrontation with Congress in 1992, although economic growth did not resume until 1993. Menem's popularity was also visibly enhanced by his success in curbing inflation in 1991-92.10

Przeworski was excessively pessimistic on privatization as well. He asserted that: 'Wholesale plans for selling state property are simply unrealistic ... “you're selling the country out to foreigners" is an accusation no government can withstand. ${ }^{11}$ In point of fact, however, ambitious privatization did take place in Argentina, Peru and, albeit more cautiously, Venezuela. Without privatization - and, in the case of Venezuela, the deregulation of the oil sector - the process of economic adjustment would have been much slower and more costly than it was - and surely less popular as a result.

The popularity of privatization varies by country, by economic sector and over time. Radical privatization in Argentina worked as well as it did partly because there existed a strong local capitalist class willing to buy state assets. While it is clear that many state assets were sold to foreigners, there were enough local purchasers to take the political sting out of the process. Privatization in Peru seems to have been popular almost irrespective of the purchaser because the performance of state-owned enterprises during the 1980 s was such a disaster. Kay quotes a survey of Peruvians in 1990 according to which 65 per cent were in favour of selling off state assets. ${ }^{12}$ Privatization seems to have been unpopular in Venezuela at the beginning of the 1990s but public opinion gradually reconciled itself to the policy. Datanalisis in Venezuela in 1996 found privatization to be a relatively popular option and expressed surprise at the finding. ${ }^{13}$ However, privatization has been unpopular elsewhere in South America. In Uruguay a plebiscite in 1992 voted heavily against a privatization proposal.

The purpose of this discussion is not simply to criticize a particular

${ }^{10}$ P. Starr, 'Government Coalitions and the Viability of Currency Boards: Argentina under the Carvallo Plan', Journal of Inter-American Studies and World Affairs, 39: 2 (Summer 1997).

"Przeworski, op. cit., p. 156.

12 Kay, op. cit., (n. 2).

is Datanalisis, Indicadores del Cambio: De que depende el exito de la Agenda Venezuela, November 1996, p. 53. 
scholar for an empirical error but rather to underline both the complexity of voter preferences and the way in which these can be changed through democratic political discussion. A public choice approach might work in principle in a world of fixed voter preferences. However, political leadership may be able to change voter preferences significantly if (for example) it can persuade people that low inf lation is beneficial and privatization harmless. Finally, even if we ignore this difficulty with Przeworski's analysis, it is still necessary to point out that the state is capable - at least under some circumstances - of pursuing an agenda of its own even at the price of some short-term unpopularity. In order to understand how far this is possible, we need to know about the government concerned as well as the policies. All governments are not endowed with an equal stock of political capital at the beginning of their term.

The sheer complexity of political life is commonly underestimated by authors who seek to formulize the politics of policy-making. For example A. Alesina (writing in a World Bank publication) asserts that the bringing of political factors into economic analysis "provides insights into how to design institutions that facilitate the achievement of efficient economic outcomes'. ${ }^{14}$ However, the conceptual world in which such designing might work must be far more simple than any real world could be.

THE NEW POPULISM, INSTITUTIONAL ANALYSIS AND DOUGLASS NORTH

It may still be too early to assess the long-run effect of the new populism upon economic performance but early indications are favourable. We certainly do know that it has proved possible to reform the economic institutions of Peru, Argentina and Venezuela under democratic government. What can we learn about this from the literature on institutions and economic development? Probably the most distinguished exposition of the argument that there is a long-term and potentially stable link between institutions and

14 A. Alesina, 'Political Models of Macroeconomic Policy and Fiscal Reforms', in S. Haggard and S. Webb (eds), Voting for Reform: Democracy, Political Liberalization and Economic Adjustment, Oxford, Oxford University Press for the World Bank, 1994. 
economic performance comes from Douglass North. ${ }^{15}$ North defines institutions as 'a set of rules, compliance procedures and moral and ethical behavioral norms designed to constrain the behavior of individuals in the interests of maximizing the wealth or utility of principals'. Later the same author defines institutions, more simply, as 'the rules of the game'. ${ }^{16}$ He argues that institutional constraints, or possibly the lack of them in some cases, make up an important part of the difference in the relative economic performance of different countries. Moreover, according to his argument, institutional behaviour is likely to be difficult to change even in the long term. He seeks to explain the differential economic performance of the United States and Latin America in terms of the longue durée, going back as far as the Spanish empire and seventeenthcentury England.

North's approach is therefore sceptical about the feasibility of achieving meaningful economic change in the short run. This is not, in itself, a major criticism. Some forms of institutional behaviour do indeed change only slowly. However, economic policy can change abruptly, and sometimes does. Two further questions come out of this. One is how far changes in economic policy do change the performance of economies. This can be answered fairly easily. Few Latin Americanists would dispute that changed economic policies in Chile after 1973 significantly improved the economic performance of that country. Government policy can make a difference. The second question is whether radical policy change is ipso facto unlikely given that institutional rules tend to reflect power relationships. There is certainly a strand in political science literature which suggests that reform in democratic systems is likely to be gradual at best. There can be no doubt, though, that the new populists have proved radical reformers. We might explore briefly why this should be so.

One reason may be that global factors now matter much more than historical-structural ones. This may be especially true in South America where elites, perhaps more than those anywhere else in the world, are highly receptive to changes in the international

${ }^{15}$ D. North, Structure and Change in Economic History, New York, Norton, 1981, pp. 201-2.

${ }^{16}$ D. North, Institutions, Institutional Change and Economic Performance, Cambridge, Cambridge University Press, 1990, p. 2. 
climate. Policy-makers faced less resistance than might have been expected when seeking to apply market-orientated reforms once these had been broadly endorsed by the international community. Globalization, at least in the sense of greater and easier capital mobility, has also significantly changed the costs and benefits attached to particular economic policies. Real interest and exchange rates in any country are largely determined internationally. International markets can reward fiscal orthodoxy, and punish unorthodoxy, much faster and more efficiently than was possible when capital markets were local and governments could extract forced savings via exchange controls and 'repressed' interest rates.

However, internal factors also seem to have been important in explaining policy change. A key point here is the fact that economic and political crises in Peru, Argentina and Venezuela did not lead to democratic breakdown. In the past, democratically elected governments in South America which presided over hyperinf lation or allowed serious popular unrest to develop were usually removed by the military. The resulting cycle of military coups and returns to elected government led to political alternation (ultimately a blind alley) rather than political development. The ability of democracy to survive in South America has made sharp changes in policy feasible during crisis periods once the need for change became selfevident.

What this seems to show is that North's treatment of institutions is too limited. It is not just that globalization has limited the scope of North's 'single-society' focus - true though this is. The problem, rather, is that it is possible for radical reformers to emerge from within an institutional framework which they subsequently change. Lasting institutional change from within authoritarian systems is possible, and democracy certainly provides a clear means via which changes can occur. All democratic institutions may be capable of transformation to some extent, and populist presidentialism may be especially propitious in bringing about radical reform. Power in presidential democracies does not emerge simply from the interaction of organizations and institutions, but from the occasionally rude intrusion of the ordinary elector as well. 


\section{POLITICAL INSTITUTIONS AND ECONOMIC REFORM}

At this point the reader might be less surprised by the fact that some South American governments have successfully adopted radical market-orientated reforms than by the fact that they have not all done so. However, the record of both market-orientated reform packages and of the political leaders attempting them has been mixed. There have been failures (Collor, Perez, Bucaram) as well as successes. What explains the different outcomes?

The key factor seems to be the ability of some individuals to enhance the powers already vested in the presidential institution. This is particularly important in the early stages of market-orientated reform because reform packages are most vulnerable to opposition early on. Later, falling inf lation and (eventually) a recovery in growth will help the government. Initially, however, there needs to be a sufficient concentration of political force at the centre to make the reform attempt effective. The comment of Brazil's President Collor, that he had one bullet to shoot the tiger, was apposite - though unfortunately he missed. Major conf lict at the initial stage may either abort the reform process altogether or so damage the government that its loss of authority is definitive. Carlos Andres Perez in Venezuela suffered from the latter problem, in that riots directed against the 1989 stabilization measures led to large-scale loss of life and the irrevocable discrediting of Perez himself.

Approached in this way, the question has to do with political institutions. Which political structures are likely to be helpful to economic reform and which are likely to prove a handicap? Most observers have generally accepted that the existence of powerful non-presidential institutions is helpful to reform. For example, Haggard and Kaufman, writing at the beginning of the 1990s, ${ }^{17}$ specifically asserted that Venezuela's strong two-party system (as it was before 1989) would facilitate economic adjustment under Perez while Peru's and Brazil's weak party systems would make effective reform unlikely. ${ }^{18}$ Their strong conclusion about Venezuela, 'it is clear that the two-party system has facilitated the imposition of

${ }^{17}$ S. Haggard and R. Kaufman, 'Economic Adjustment and the Prospects for Democracy', in Haggard and Kaufman (eds), The Politics of Economic Adjustment, Princeton, Princeton University Press, 1992.

18 Ibid., p. 313. 
stabilization programs in a democratic context', has clearly not stood the test of time. The economic stabilization programme imposed by Carlos Andres Perez in $\mathbf{1 9 8 9}$ failed across a variety of fronts. It led to major riots leading, in turn, to the killing of very many Venezuelans through over-reaction by the security forces. ${ }^{19}$ All of this made the government so intensely unpopular that even significant economic recovery after 1990 did not restore the government's reputation. Independent surveys clearly brought out the low level of government popularity before the coup attempts of February and November 1992 and the dislike of economic stabilization measures. ${ }^{20}$ The political isolation of the government after the first coup attempt aborted the economic reform programme, since Congress simply refused to vote for tax reforms or other unpopular measures when the government requested it to do so - irrespective of the fact that the government had a congressional majority and party discipline was theoretically strong. As a result, Venezuela returned to having a fiscal deficit financed by domestic borrowing at high interest rates. This combination created serious problems for the domestic banking sector, already vulnerable because of large-scale corruption and unreformed by Perez. (The banking system to all intents and purposes collapsed in the spring of 1994.) When corruption allegations were added to the post-coup ferment, Perez was impeached and removed from office in 1993. Not even a major internal reform to the governing Acción Democrátia (AD) party saved it from defeat in the elections of that year.

By the same token Haggard and Kaufman argued of Brazil and Peru that, in view of the need to stabilize the high rates of inf lation which existed at the beginning of the 1990s, 'the prospects are poor not only for adjustment but for democracy as well'. Yet these countries have actually been rather more successful in achieving structural adjustment within a climate of popular support than were the party politicians of pre-1993 Venezuela. Comparison between contemporary and pre-1990 Peru would be even more telling.

Haggard and Kaufman proved to be poor predictors because their work embodies a key problem of much comparative politics - that

$19 \mathrm{~W}$. Little and Herrera, Populism and Reform in Contemporary Venezuela, ILAS Occasional Paper 11, London, 1994.

${ }^{20}$ G. Philip, 'The Venezuelan Coup Attempt of February 1992', Government and Opposition, 26: 4 (Autumn 1992). 
of misplaced concreteness. The misguided assumption is that key non-presidential institutions (such as parties, trade unions and Congress) actually work more or less as they should on paper. In South America (as elsewhere) political parties which perform as they should continue to enjoy the respect of the electorate: the Chilean Christian Democratic Party would serve as an example. However, if electorates come to perceive (perhaps correctly) that their 'representative' institutions are corrupt and out of touch, then these will provide little support to governments which need to pursue unpopular policies. The danger is that the unpopularity of 'corrupt' non-presidential institutions and the natural popular dislike of some aspects of market-orientated reform programmes will become selfreinforcing and cumulative. ${ }^{21}$

Corruption may be a simple word, but it carries considerable resonance. When a panel of Venezuelans were asked in 1995 what they considered to be the most valuable characteristic in a political leader, 68 per cent replied 'honesty', ${ }^{22}$ while 88 per cent of the same panel had 'little' or 'no' confidence in Venezuela's political parties. ${ }^{23}$ Popular perceptions of corruption, where these are widespread, are not usually false. The involvement of party politicians in corruption in Venezuela during the 1980 s was comprehensive, disgraceful and thoroughly publicized within the country. ${ }^{24}$

In Peru the decay of the pre-1990 parties went even further. In both 1990 and 1995 both the winner and the runner-up in presidential elections were independent candidates (in 1995 the third-placed candidate was also an independent). The only significant electoral defeat suffered by Fujimori since 1990 was sustained when Andrade, a private businessman with no party-political affiliation, was elected mayor of Lima in 1995 in preference to the progovernment candidate. The Peruvian electorate appears to have agreed with Vargas Llosa that a high proportion of the country's

${ }^{21}$ A. Romero, 'Rearranging the Deckchairs on the Titanic: The Agony of Democracy in Venezuela', Latin American Research Review, 32: 1 (1997).

22 Fundación Pensamiento y Acción, Cultura Democratica en Venezuela: informe analitico de los resultados de una encuesta de opinion publica, Caracas, January 1996, p. 5.

${ }^{23}$ Ibid, p. 47.

$24 \mathrm{~W}$. Little and A. Herrera, 'Political Corruption in Venezuela', in W. Little and E. Posada-Carbo (eds), Political Corruption in Latin America, London, Macmillan, 1996, pp. 267-87. 
politicians 'were ardent followers of the moral philosophy that a Peruvian politician summed up in the words: "To live without your expenses accounted for in the annual budget is to live in error"' ${ }^{25}$

The point is that there are circumstances in which the 'dual legitimation' of presidential systems - which has been regarded in the literature as a serious weakness ${ }^{26}$ - can be a strength. Successful populists can reach the presidency free from the stigma which will almost inevitably attach to insider politicians in a corrupt system. Their ability to carry out reforms will not be hindered by association with problems of the past. Moreover when reforms are threatened by opposition from non-presidential institutions, they may enjoy popular backing in any subsequent confrontation. For such a strategy to work, however, the successful populist must not be vulnerable himself to 'smoking-gun' accusations of corruption. Populists against whom allegations of corruption were made to stick - Collor in Brazil and Bucaram in Ecuador - were promptly removed from office by Congress.

Populist presidentialism is therefore most likely to succeed where non-presidential institutions are seen by their electorates as corrupt and self-interested and the populists as sincere reformers. They are unlikely to pose much threat to established political institutions when these are working well, while populists who visibly overstep the mark are unlikely to be forgiven. Critics of the new populism, where this does succeed, sometimes make the mistake of blaming the undertaker for the murder. For example, Bresser Pereira has claimed that populism 'tends to undermine representative institutions, to personalise politics and to generate a climate in which politics become reduced to fixes... neoliberal packages ... are likely to generate voodoo politics'. ${ }^{27}$ This sums up an attitude that is quite widely held. However, it is based largely on a perception of how things 'ought' to have been in Peru, Argentina and Venezuela before the election of Fujimori, Menem and Caldera - and not on how they actually were.

${ }^{25}$ M. Vargas Llosa, 'A Fish out of Water', in Granta special issue Vargas Llosa for President, 1991.

${ }^{26} \mathrm{~J}$. Linz, 'Presidential or Parliamentary Democracy: Does it Make a Difference?', in J. Linz and A. Valenzuela, The Failure of Presidential Democracy, Baltimore, Johns Hopkins University Press, 1996, pp. 3-91.

${ }^{27}$ L. Bresser Pereira, J. Maravall and A. Przeworski, Economic Reforms in New Democracies, Cambridge, Cambridge University Press, 1993, pp. 9-10. 


\section{PRESIDENTIALISM, POPULISM AND DEMOCRACY}

From the perspective of democratic theory, the new populism may be seen as second best to well-functioning institutional democracy. Many criticisms of over powering presidentialism are certainly valid. Democratic presidential systems are undoubtedly fragile in the absence of legitimate non-presidential institutions, and charismatic authority needs routinization. Nevertheless, there are also problems with an interpretation of democracy which is excessively geared to the notion of checks, balances and procedures. It is all very well if they work, but what happens when they do not? One way for a corrupt system to undergo reform is via decisive executive action. Apart from arguments about 'necessity' in such cases, there is also the fact that strong presidentialism may at times be a genuine reflection of the popular will. Successful democratic systems give weight to two ideas, which at times coexist uneasily. Democracy is partly about self-government, popular sovereignty and the will of the people. It is also partly about individual rights, due process and freedom under law. The two notions can conflict. In Peru, Argentina and Venezuela, the conflict between the two became particularly acute at the end of the 1980s and it was resolved - temporarily - in favour of majoritarianism. It may be that there is something in the political culture of South America as a whole which gives more weight to majoritarianism and less to rights than is generally the case in the United States. ${ }^{28}$

Pure majoritarianism may be undesirable for a number of reasons. We have already seen that elected governments can sometimes give rather little weight to individual rights. It is clear that the rule of law in Fujimori's Peru does not significantly constrain the behaviour of the security forces, which have on occasion literally been allowed to get away with murder. Furthermore there are strong historical reasons, in South America as elsewhere, to worry about the consequences of arbitrary government. For these reasons, international organizations concerned with elaborating and promoting the notion of 'good government' have emphasized the virtues of constraining power rather than those of strong government.

${ }^{28}$ F. Panizza, 'Human Rights in the Processes of Transition and Consolidation of Democracy in Latin America', Political Studies, Special Issue 1995: Politics and Human Rights. 
However, an exclusive concentration on rights issues and the virtues of procedure can be problematic as well. This is particularly the case when existing institutions are seen as radically corrupt and without the means of self-reform, or when they are manifestly helpless in the face of economic crisis or the breakdown of order. Institutional systems which emphasize checks and balances may tend towards equilibrium (or stagnation if one adopts a different standpoint) while majoritarianism can be a force making for real change. The realpolitik, at least in South America, is that democracies which fail to change in times of crisis may be vulnerable to replacement by non-democracy.

Majoritarian populism, of any kind, is unlikely to be stable in the long term. Popularity is inevitably a fickle resource. As economies recover, electorates are likely to expect more and become increasingly resentful of authoritarian styles of politics. Opinion poll surveys are starting to pick up signs that anxiety about the abuse of human rights (primarily in Peru) and about corruption (primarily in Argentina) are now influencing voters to a significant extent. The temporary success of some forms of populism should not be taken as evidence of the final triumph of what O'Donnell has called 'delegative democracy'.$^{29}$ South America's democratic institutions, like those elsewhere, are capable of continuing development and change.

\section{CONCLUSION}

In 1980 a candidate for the US presidential nomination, George Bush, accused his main Republican opponent, Ronald Reagan, of advocating 'voodoo economics'. Reaganomics in the event proved controversial, but Reagan proved to be a popular president. Technocratic orthodoxy was one thing, and democracy another. Democratic leaders in touch with public opinion may be more successful than theoretical purists might suppose.

A similar conclusion seems in order here. According to the 'politics of development' literature, the new populism should not have emerged. If it had, then it should not have succeeded. It did emerge because orthodox democratic alternatives failed and because

29 G. O'Donnell, 'Delegative Democracy', Journal of Democracy, 5: 1 (1994). 
of the historical resonance of populist appeals in South America. It succeeded, above all, because democracy allows electorates to make their own choices and to hold governments accountable when things go wrong.

It would be a mistake to believe that policy issues can be separated from institutional ones. They are connected by the exercise of power. To understand the way in which this connection is made in specific circumstances requires a more sensitive understanding of particular contexts than some scholars - more concerned with theoretical rigour than specific detail - have been willing to provide. The literature has, too often, offered up either institutions without policy change (via Douglass North) or policy analysis without institutional variances (via the public choice theorists). Even authors who have focused directly upon institutions have at times been wishful and normative rather than dispassionately focused on the way power can actually be exercised. This does not mean that one should be starry-eyed about power and those who wield it, but democracies do need leadership. The political successes of Menem, Fujimori and Caldera have come from their ability to mobilize and wield power - thereby reforming both political institutions and economic policy. If populist reformism is to be characterized as 'voodoo politics', then at least it can be said that Macumba came.

There is a further problem with much current 'politics of development' literature. Analytical narrowness can sometimes become judgmental narrowness. This is particularly a matter of concern given the way in which powerful international organizations are (among other things) seeking to spread the practice of 'good government'. 'Good government' - if this is understood as government through institutions designed according to some preconceived formula - will not necessarily be popular, legitimate or even effective unless based upon the political realities of the country concerned.

In the end, the great virtue of democracy is not that it corresponds to some neat formula of rule but rather that power is vested in the people. It is clear that democratic systems are capable of producing some degree of unpredictability and forcing observers to rethink. This is surely one of their great virtues. We still have more to learn about the ways in which people in South America view their own political institutions, but what we do know should be taken more seriously than it sometimes is. 